\title{
Community-acquired pneumonia in Europe: causative pathogens and resistance patterns
}

\author{
M. Woodhead
}

\begin{abstract}
Community-acquired pneumonia in Europe: causative pathogens and resistance patterns. M. Woodhead. (C)ERS Journals Ltd 2002.

ABSTRACT: Community-acquired pneumonia (CAP) is a common condition affecting about 1/1,000 of the adult population per year. It occurs when bacteria enter the alveolar spaces of the lung initiating an inflammatory response which leads to the clinical features of cough, sputum production, breathlessness and sometimes chest pain and haemoptysis.

At the end of the last century the causal relationship between bacteria and pneumonia was established and many of the early discoveries about the causes of CAP were made in Europe. Some 41 different prospective studies have established that $\sim 10$ different microbial pathogens regularly cause CAP with occasional cases due to other rarer causes. The frequency of these organisms in Europe is similar in most countries, but there are some geographic differences. Differences in frequency are also apparent according to illness severity. It is generally recognised that Streptococcus pneumoniae is the most important causal bacterium in all countries.

A relatively recent development has been the appearance and spread, in some of the common causative bacteria, of resistance to commonly used antibiotics to which they were once sensitive. The frequency of such resistance does vary markedly between European countries.

However, published data is often difficult to interpret. The reasons for this are that the frequency of resistance varies according to the age of the patient, the site of the sample, the clinical diagnosis, the use of prior antibiotics and the influence of special groups $e . g$. those with cystic fibrosis. The impact of in vitro antibiotic resistance on clinical outcome is still poorly understood, but recent studies are helping to clarify this issue and will be discussed.

Eur Respir J 2002; 20: Suppl. 36, 20s-27s.
\end{abstract}

\author{
Correspondence: M. Woodhead \\ Dept of Respiratory Medicine \\ Manchester Royal Infirmary \\ Oxford Road \\ Manchester \\ M13 9WL \\ UK \\ Fax: 441612764989 \\ E-mail: woodhead@ \\ central.cmht.nwest.nhs.uk
}

Keywords: Aetiology

bacterial resistance

community-acquired pneumonia

Streptococcus pneumoniae

Received: January 282002

Accepted after revision: January 31 2002
Pneumonia is caused by microbial infection in the lung. It is a condition characterised pathologically by inflammation both within and around the alveolar spaces of the lung known as consolidation. Occlusion of the alveolar spaces disrupts the normal gas exchange function of the lung leading to the clinical symptoms of dyspnoea, cough and expectoration, and the physical signs of bronchial breathing, crackles and dullness to percussion. Inflammation may give rise locally to pain and systemically to the fever, anorexia and lethargy that are features of the condition. Such clinical features are variably present in patients with pneumonia and are shared with other respiratory infections. It is the consolidation, which can be visualised as shadowing on a chest radiograph, which distinguishes pneumonia from most other infective lower respiratory tract pathologies. This raises the potential problem that without a chest radiograph the diagnosis cannot be made with certainty. In the community where pneumonia is most common and ready access to radiographic facilities is not always available a clinical diagnosis can be accepted, but with the knowledge that this is neither as sensitive nor as specific as radiographic diagnosis.
The causative pathogens, methods of acquisition and outcomes differ in different types of pneumonia leading to the recognition of three broad types of pneumonia. These are community-acquired and hospitalacquired (nosocomial) pneumonias and pneumonia in the immunocompromised. Only the former is dealt with in this paper.

Community-acquired pneumonia (CAP) is common, although precise figures are not available for most European countries, because appropriate studies have not been performed. Studies in Spain [1, 2], Finland [3] and England [4] have suggested frequencies of 1.6, 2.6, 4.7 and 9 cases per 1000 of the general adult population per year. The frequency of the condition is age-related with the highest rates in the very young and very old. A study from Finland found rates of 36 of 1000 in those aged $<5$ yrs falling to 4.4 of 1000 in the 15-29 age group and rising again to 34.2 of 1000 in those aged $>74$ yrs [3]. Of those in the community, between 8\% [5] and 51\% [1] are admitted to hospital and between $4 \%$ and $15 \%$ of such patients will die. Its frequency, morbidity and mortality are the reasons why CAP is such an important disease. Eradication of the causative organism(s) is a fundamental 
step in the management of the patient with pneumonia. At presentation, clinical and laboratory features do not allow prediction of microbial cause in an individual case. Knowledge of likely causative pathogens from prospective studies to direct appropriate treatment is vital. Until recently the antibiotic sensitivities of causative bacteria were thought to be stable. The emergence and spread of resistance to commonly used antibiotics has now challenged this view and added another dimension to the management of CAP.

\section{Historical issues}

CAP is a condition that was identified in ancient times with the first cases being recognised in the Mummies of Egyptians who lived between 1250 and 1000 BC. In Europe, it was first described by the Ancient Greeks and was known as a "peripneumonia". Pneumonia continues to appear in documents at various times through European history with, for example, a clear description of the condition appearing in the writings of Thomas Willis in the seventeenth century in England [6]. LAENNEC [7] in 1830 was the first to describe the pathological changes of pneumonia.

Many of the initial discoveries linking microbial pathogens to pneumonia occurred in Europe. In 1875, KLEBS [8] found bacteria in the bronchial contents of patients dying of pneumonia, but did not appreciate their significance. In France in 1881, PASTEUR [9] was the first (followed 3 months later by STERNBERG [10] working in New Orleans) to recover what is now known to be the pneumococcus, from rabbits injected with the saliva from a child who had died from rabies: ". . . le sang des animaux est envahi par un organisme microscopique dont les propriétés sont fort curieuses." (the animal's blood is invaded by a microorganism whose properties are very strange).

In 1882/1883, FrIEDLANDER $[11,12]$ was the first to suggest a causal relationship between bacteria and pneumonia, having found such organisms in the lungs of nearly all of 50 patients with pneumonia. This was followed in 1886 by the first comprehensive microbiological study of patients with pneumonia performed by WeichSELBAUM [13]. This study reported 129 cases of pneumonia in which Streptococcus pneumoniae was found in 94, Klebsiella pneumoniae in nine and Staphylococcus aureus in five. In the twentieth century, most discoveries in the field of pneumonia aetiology related to atypical pathogens and viruses, with many of the new discoveries being made outside Europe. In the USA, the term atypical pneumonia was coined by REIMANN [14] in 1933, and the "Eaton Agent", subsequently to be called Mycoplasma pneumoniae, was identified as the cause [15]. Although psittacosis was first described in Switzerland in 1880 [16], the causative organism was not described until 1930, and then simultaneously in England, Germany and the USA. The influenza virus was discovered in England in 1933 [17] and Coxiella burnetii, the cause of $\mathrm{Q}$ fever was discovered in Australia in 1937 [18]. Most recently legionella bacteria (1977) [19] and Chlamydia pneumoniae (1986) [20] were discovered in the USA. Although the existence of sulphonamide-resistant pneumococci [21], tetracycline resistance [22] and erythromycin resistance [23] were established as long ago as 1943, 1962 and 1967 respectively, it was only the finding of penicillin-resistant pneumococci in clinical specimens in New Guinea in 1967 [24], and at about the same time in South Africa, that caused alarm. Since then antibiotic resistance in pneumococci has become a worldwide issue. It is against this background that studies of the microbial cause of CAP are founded. Such studies tend to be performed in three separate settings: the community, the hospital ward and the intensive care unit (ICU), which equates to the three grades of illness severity, mild, moderate and severe.

\section{Methodological issues}

There are a number of issues which may confound the results of aetiological studies in CAP. Without knowledge of these it is possible to wrongly conclude that the causative organisms in two studies are the same when they may not be, and also that they are different when in fact they may be the same. These issues can be divided into healthcare delivery, population, epidemiological and study methodology factors.

The first factors are those related to healthcare delivery. As indicated earlier the proportion of patients admitted to hospital varies from country to country. The reasons for this are not fully understood but one implication is that the in-hospital population covered in one study may be the same as, or overlap with, the community population covered in another study. Criteria for ICU admission vary from hospital to hospital and, for example, intubation rates are quite different in separate ICU studies of CAP, ranging from $50 \%$ [25] to $100 \%$ [26] even within the same country. Thus different populations of patients may be being studied.

Several factors relating to the population being studied may have an impact on aetiological results. These include the number of patients studied, the age mix, and the frequency of factors such as prior influenza and pneumococcal vaccination, antibiotic therapy, alcoholism, immunosuppression and comorbid disease, especially malignancy. Some studies exclude some of these patient groups, others do not. Studies of patients where $25 \%$ are immunocompromised [27] should not be compared with others from which such patients have been excluded. The impact of age appears to be mainly on the frequency of mycoplasma infection which is less common in the elderly [28]. This may be true also for legionella infection [28].

The frequency of causative organisms may not be static over time. Some show a natural seasonal periodicity (e.g. Q fever is more common in the Spring [29]) while others, such as mycoplasma vary over longer intervals and may be unpredictable [28]. Studies should be long enough to capture short-term, 
seasonal variations and need to acknowledge the epidemic nature of other organisms.

Some aspects of study methodology (e.g. case mix, duration) have already been covered. Other important factors include the nature and comprehensiveness of sample collection, the actual microbiological investigations performed and the rules governing result interpretation. Studies that use sensitive methods for the detection of $S$. pneumoniae find a higher frequency of this organism than those that do not [28]. While many of these issues are covered in the methodological section of such publications, very often they are not explicitly stated, which makes result interpretation difficult. To compare the importance of pathogens between European countries the ideal study would use the same study methodology simultaneously in each country. No such study has been undertaken. For these reasons single studies need to be interpreted with caution and the results only accepted if supported by other similar studies.

\section{Causative pathogens}

Some 41 prospective studies of the aetiology of CAP in European countries have been published and form the basis for this section of the paper $[1,2,4,5$, $25,26,30-64]$. As indicated above, CAP in the community is the most difficult to define and study, and is therefore the least known with only eight studies published. Twenty-three have been performed on patients admitted to hospital and 13 on those admitted to the ICU. Of these, most have been performed in Spain [13], the UK [10] and Sweden [6] and therefore the causative pathogens are best understood for these countries. No such studies have been performed in a number of European countries and are urgently needed.

The results of these studies show that a number of different microbial pathogens regularly cause CAP in each clinical setting (table 1). The most frequent organism, as in Weichselbaum's 1886 study [13], is

Table 1. - Frequency of causative organisms

Organism Community Hospital ICU

\begin{tabular}{lccc}
\hline Studies $^{\#}$ & 9 & 23 & 13 \\
Streptococcus pneumoniae & 19.3 & 25.9 & 21.7 \\
Haemophilus influenzae & 3.3 & 4.0 & 5.1 \\
Legionella spp. & 1.9 & 4.9 & 7.9 \\
Staphylococcus aureus & 0.2 & 1.4 & 7.6 \\
Moraxella catarrhalis & 0.5 & 2.5 & \\
Gram-negative enteric bacteria & 0.4 & 2.7 & 7.5 \\
Mycoplasma pneumoniae & 11.1 & 7.5 & 2 \\
Chlamydia pneumoniae & 8 & 7 & \\
Chlamydia psittaci & 1.5 & 1.9 & 1.3 \\
Coxiella burnetii & 0.9 & 0.8 & 0.2 \\
Viruses & 11.7 & 10.9 & 5.1 \\
Other organsims & 1.6 & 2.2 & 7.4 \\
No pathogen identified & 49.8 & 43.8 & 41.5 \\
\hline
\end{tabular}

Data are presented as percentage means from the included studies. \#: 41 studies in total; Some studies separated patients according to setting and therefore the total number of studies is $>41$. ICU: intensive care unit.
$S$. pneumoniae. This is true for each of the three clinical settings. The average figures give the impression that it may be less frequent in those managed in the community, but inspection of the individual studies (fig. 1) shows wide variation in frequency, unrelated to setting and perhaps more likely to be related to methodology as previously suggested. No difference in frequency between countries is apparent (data not shown).

The most frequent category in all settings represents those patients in whom no pathogen was identified. This primarily reflects the great difficulty involved in mounting such studies. Debate continues as to the cause of the illness in this group. Undoubtedly, there is more than one cause for failure to identify a causal pathogen, including the inclusion of noninfective illness that mimics CAP. Some may be caused by organisms that are difficult to identify by conventional microbiological methods, such as anaerobic bacteria, others by organisms that have yet to be described. However, some studies suggest that most of these cases are due to "missed" pneumococcal infection. This is supported by the similar clinical and laboratory features in these cases compared to those with proven pneumococcal infection [65] and the ability to find evidence of pneumococcal infection in up to $75 \%$ of cases if great care is taken in investigation [47]. In the $>100$ yrs since Weichselbaum's study [13], although new pathogens have been identified, the pneumococcus has remained the number one cause of CAP.

$S$. aureus, legionella and Gram-negative enteric bacteria are uncommon in disease managed outside hospital, but show a pattern of progressive increase in frequency with increasing illness severity. This is true for the average figures and for individual studies (fig. 2; data for $S$. aureus and Gram-negative enteric organisms not shown). All are found rarely in those with mild illness, such as is generally managed in the community. For $M$. pneumoniae the converse is true, with rising frequency as illness severity decreases (table 1, fig. 3). Other factors which complicate the interpretation of data concerning these organisms include: the tendency of staphylococcal infection to

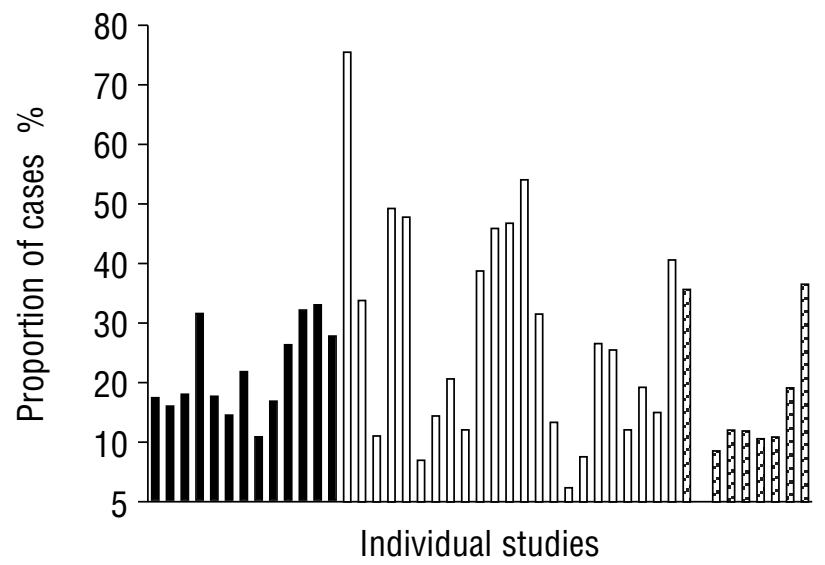

Fig. 1.-Frequency of identification of Streptococcus pneumoniae in prospective studies. $\square$ : studies in the intensive care unit; $\square$ : studies in the hospital; $\mathbb{Z}$ : studies in the community. 


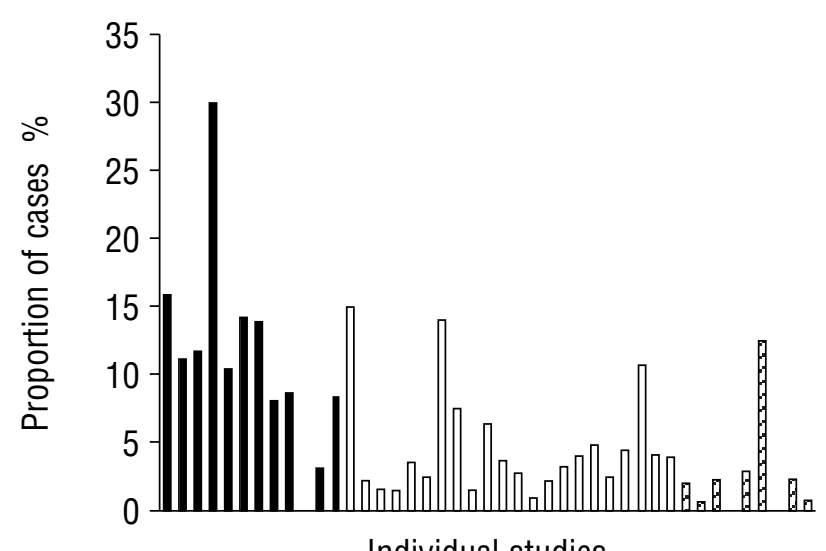

Fig. 2.-Frequency of identification of Legionella bacteria in prospective studies. $\mathbf{\square}$ : studies in the intensive care unit; $\square$ : studies in the hospital; $\mathbb{Z}$ : studies in the community.

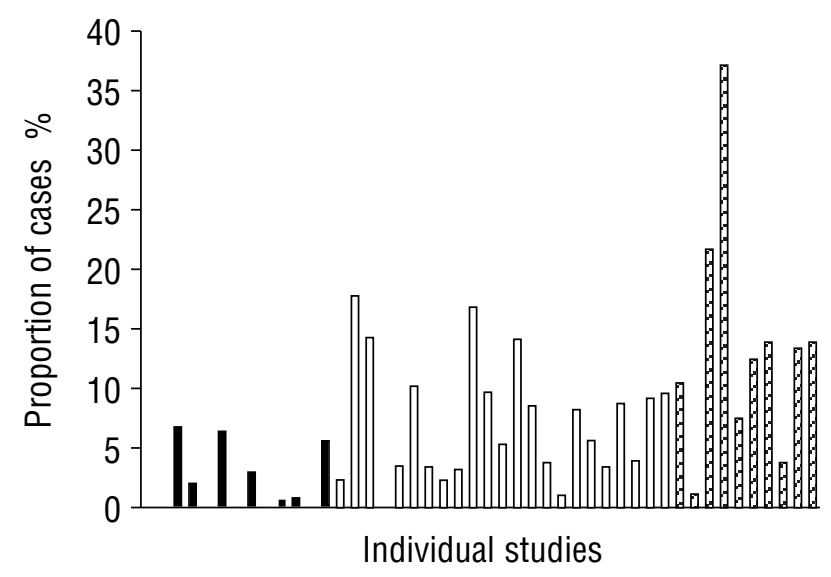

Fig. 3.-Frequency of identification of Mycoplasma pneumoniae in prospective studies. $\boldsymbol{\square}$ : studies in the intensive care unit; $\square$ : studies in the hospital; $\mathbb{Z}$ : studies in the community.

follow influenza viral infection, the variability of mycoplasma infection leading to epidemics every $\sim 4$ yrs in some countries, and the lack of objective confirmation of Gram-negative enterobacterial infection, which is often based only on sputum isolates.

Haemophilus influenzae is a regular cause of CAP, but is not particularly common and, contrary to popular ideas, appears to be no more common in those with underlying chronic obstructive pulmonary disease (COPD) [66]. Moraxella catarrhalis seldom causes CAP.

Legionella organisms may vary in importance in different countries [46, 62], although this is not shown clearly from prospective studies, partly because of the infrequency of studies from countries where the organism is thought to be uncommon and by other studies in what might be local "hot spots" for legionella infection which may not represent the country as a whole $[47,48,67]$. There is a perception that the Legionella organism is more important in Mediterranean countries [62], and is uncommon in Northern European countries, other than in travellers from these areas or in the context of a local source of infection.
C. burnetii is a rare cause of CAP. There does appear to be geographic variation in frequency, with the organism virtually absent in some parts of Scandinavia [46], but second only to $S$. pneumoniae as a cause in e.g. North West Spain [68].

C. pneumoniae is one of the least well understood organisms as it has only been detected in the most recent studies. It may occur in epidemics in some countries and is often complicated by bacterial co-infection which has led to the suggestion that the secondary bacterial infection is the cause of the pneumonia [51, 69].

Chlamydia psittaci is an uncommon cause of CAP and is usually related to bird or sheep contact.

The role of viruses as primary causes of CAP, as opposed to the initiators of secondary bacterial infection, is incompletely understood. Until recently, this has been further confounded by the lack of availability of sensitive methods for their detection. Influenza viruses are those most frequently identified in published studies.

The issue of mixed infection remains unresolved. That a single causative pathogen is responsible for the episode of CAP in an individual has long been assumed. However, more than one pathogen has been identified in some patients, sometimes two bacteria, sometimes one bacterial with either a viral or atypical pathogen and occasionally more than two bacteria have been found. The frequency of this phenomenon varies between studies for a number of reasons, most importantly depending on diagnostic methods. While many studies show a frequency of $<10 \%$ of cases, as many as $27 \%$ [51] have been recorded as due to mixed infection in one study. In circumstances where more than one organism is identified it may be that both contribute to the pneumonia, but in most cases it is more likely that one agent may have been the initiating factor, e.g. by damaging the bronchial mucosa, and that it is the other organism that has caused the pneumonia. The relative importance of these two mechanisms is not known.

\section{Antibiotic resistance}

From the discussion above, it is apparent that it is antibiotic resistance in $S$. pneumoniae that is of most potential importance in CAP. Any discussion of this issue must encompass what is meant by "antibiotic resistance", how data about this is gathered and the relevance of in vitro measures to clinical outcomes.

Many studies have been undertaken to determine the frequency of antibiotic resistance in pneumococcal isolates. These have established that the frequency of such resistance is altered by a number of factors including: the site of the sample (e.g. higher frequency in upper respiratory tract isolates), the age of the patient (e.g. usually higher in children) and the clinical setting (e.g. usually higher in hospital or ICU isolates compared to those from the community). Many studies reflect the experience from one microbiology laboratory and as such are open to bias, as data reflects what arrives at the door rather than being collected prospectively, and may be altered by an 
excess of certain patient groups e.g. human immunodeficiency virus (HIV), cystic fibrosis. This probably explains the apparent difference in the frequency of resistant bacteria between two hospitals within the same city [70]. Frequently, the exact clinical source of the samples is not explicitly stated. In the context of adults with CAP, it is important that data derived from samples from unselected adults with CAP is used. Prospective studies would be the best source of such data, however, this is available in only three studies published in the last 3 yrs. Pneumococcal resistance (variably defined) was found in none of 12 [71], one of 18 [51] and 9 of 30 [72] cases. One reason for the poor quality of this data is that in many studies the majority of pneumococcal infections are diagnosed by indirect methods that do not involve culture of the organism [51]. It is only when molecular tools for resistance determination, that function in the absence of the intact pathogen, are available will a true picture of the frequency of resistance in $S$. pneumoniae emerge. Data from invasive isolates is relevant since most, but not all, bacteraemias arise from CAP and these represent the patients with severe illness who are most likely to die. However, such data may not be relevant to CAP in the community. Data from patients with "lower respiratory tract infection" [73] may also not be useful in the context of CAP since most of these patients have exacerbations of COPD where both the bacterial causes and the resistance patterns may be different.

What is known is that the frequency of antibiotic resistance in $S$. pneumoniae varies according to country across Europe. Data for invasive isolates collected in 2001 by the European Antimicrobial Resistance Surveillance System (EARSS) identifies Spain and Greece as having the highest $(>30 \%$ of isolates) frequencies of penicillin resistance, followed by $10-29 \%$ in Belgium, Poland, Hungary and Slovenia [74]. The Netherlands, Germany, Austria and Bulgaria had levels of $<3 \%$. Data from some countries (e.g. France, Eastern Europe) were missing from this analysis. In nearly all countries, resistance rates are rising.

From the clinician's perspective, resistance measures should reflect levels at which clinical failures are likely to occur. These may differ in different parts of the body since resistance is graded rather than being absolute. The same orally administered dose of penicillin will lead to much lower antibiotic levels in the cerebrospinal fluid (CSF) than in serum or the lung. This means that the same dose of penicillin may kill a pneumococcus in the lung when it will not in the CSF. In 2000 acknowledgement of this principal led to the recommendation that, for pneumonia, penicillin susceptibility categories should be shifted upward so that the intermediate category included isolates with a minimum inhibitory concentration (MIC) of $2 \mu \mathrm{g} \cdot \mathrm{mL}^{-1}$ and that the resistant category included isolates with an MIC of $\geqslant 4 \mu \mathrm{g} \cdot \mathrm{mL}^{-1}$ [75]. In producing this statement it was recognised that only limited data were available linking such levels with treatment success or failure. It must not be forgotten that clinical failures occur in pneumococcal pneumonia caused by fully sensitive organisms [76]. High-level
$\left(\mathrm{MIC}>1 \mu \mathrm{g} \cdot \mathrm{mL}^{-1}\right)$ penicillin resistance has been linked to increased mortality in a study of pneumococcal bacteraemias of all ages, including 50\% who were HIV positive [77]. In another study of bacteraemic pneumococcal pneumonia, which included $25 \%$ with HIV infection and 15\% with "active cancer", those with nonsusceptible pneumococcal infection (MIC $\geqslant 0.1$ ) had a relative risk of death of 2.1 (95\% confidence interval 1-4.3) [78]. However, a Spanish study, suggested that drug resistance overall does not affect community-acquired pneumococcal pneumonia severity, length of hospital stay or mortality [79]. In another study in Barcelona, which included both nosocomial and community-acquired bacteraemic pneumonias, only two treatment failures occurred with MICs of 4 and 8 respectively [80]. More recently a large study of bacteraemic pneumococcal pneumonia found that deaths after 4 days of admission (those before 4 days were considered to be unpreventable by antibiotic therapy) were associated with penicillin MICs of $\geqslant 4 \mu \mathrm{g} \cdot \mathrm{mL}^{-1}$ and cefotaxime MICs of $\geqslant 2 \mu \mathrm{g} \cdot \mathrm{mL}^{-1}[81]$. Most publications refer to "resistance" using the older classification in which such bacteria would now be considered to be susceptible. There are no studies to date for CAP in Europe that indicate the frequency of isolates with an MIC of $\geqslant 4 \mu \mathrm{g} \cdot \mathrm{mL}^{-1}$, which is what the prescriber would want to know most [82]. A recent prospective treatment study from Barcelona found that only 10 of $116(9 \%)$ adults admitted to hospital with pneumococcal pneumonia had pneumococci with an MIC of $\geqslant 2$ [83]. Outcome was the same in the co-amoxiclav treated group as in the ceftriaxone treated group. Currently incomplete evidence suggests that although penicillin resistance is common, it is rarely a cause of treatment failure in adults with CAP.

For macrolide resistance, EARSS data suggest that Spain and Belgium have the highest rates of invasive isolates of $S$. pneumoniae. Data from other sources suggests that this resistance is also common in France [73]. The clinical relevance of in vitro resistance measures is perhaps even less clear than it is for penicillin resistance [84]. While anecdotal reports [85] have linked clinical failure with macrolide resistance there is no data to suggest that this is a widespread phenomenon.

The development of new quinolone antibiotics with enhanced activity against $S$. pneumoniae, compared to ciprofloxacin and ofloxacin, has rapidly been followed by reports of quinolone resistance [86]. The frequency and clinical relevance of this is not yet known.

\section{Conclusions}

The common microbial causes of CAP have now been documented. It is clear that a number of different pathogens are relevant, but that $S$. pneumoniae remains the most important. Although the data is incomplete geographic variations in microbial incidence, while present, do not follow national boundaries.

Antibiotic resistance, particularly in $S$. pneumoniae, is a common and growing phenomenon. Since this is 
largely a man-made phenomenon influenced by public expectations and national prescribing practices it is perhaps not surprising that differences in frequency are divided by national boundaries.

There remains much that is still unknown. Data from prospective studies on the aetiology of communityacquired pneumonia are restricted to a few European countries, with most performed in the UK and Spain and few in the community. It will be important to reinforce the available data with new data from other countries in the next few years. Only now is clinically useful data on antibiotic resistance beginning to be collected following the development of a clinically meaningful definition for penicillin resistance in pneumococci causing community-acquired pneumonia. Until this is done it will not be possible to understand the true importance of this phenomenon in the management of patients with communityacquired pneumonia.

\section{References}

1. Almirall J, Morato I, Riera F, et al. Incidence of community-acquired pneumonia and Chlamydia pneumoniae infection: a prospective multicentre study. Eur Respir J 1993; 6: 14-18.

2. Almirall J, Bolibar I, Vidal J, et al. Epidemiology of community-acquired pneumonia in adults: a population-based study. Eur Respir J 2000; 15: $757-$ 763.

3. Jokinen C, Heiskanen L, Juvonen $\mathrm{H}$, et al. Incidence of community-acquired pneumonia in the population of four municipalities in Eastern Finland. $A m ~ J$ Epidemiol 1993; 137: 977-988.

4. Woodhead MA, Macfarlane JT, McCracken JS, Rose DH, Finch RG. Prospective study of the aetiology and outcome of pneumonia in the community. Lancet 1987; i: 671-674.

5. Bochud PY, Moser F, Erard P, et al. Communityacquired pneumonia. A prospective outpatient study. Medicine (Baltimore) 2001; 80: 75-87.

6. Willis T. Of a peripneumony, or inflammation of the lungs. In: Dring T, Harper C, Leigh J, eds. Dr Willis's practice of phyfick. London, 1684; pp. 57-70.

7. Laennec RTH. A treatise on diseases of the chest and mediate auscultation. New York, Samuel Wood \& Sons, 1830.

8. Klebs E. Beitrage zur Kenntniss der pathogenen Schistomyceten. Arch Exptl Pathol Pharmacol 1875; 4: 409-488.

9. Pasteur L. Note sur la maladie nouvelle provoquee par la salive d'un enfant mort de la rage. Bull Acad Med (Paris) 1881; 10: 94-103.

10. Sternberg GM. A fatal form of septicaemia in the rabbit, produced by subcutaneous injection of human saliva. An experimental research. Nat Board Health Bull 1881; 2: 781-783.

11. Friedlander C. Ueber die Schizomyceten bei der acuten fibrosen Pneumonie. Virchows Arch Pathol Anat Physiol Klinische Medizin (Berlin) 1882; 87: 319_ 324.

12. Friedlander C. Die Mikrokokken der Pneumonie. Fortschr Med 1883; 1: 715-733.

13. Weichselbaum A. Ueber die Aetiologie der Acuten
Lungen und Rippenfellentzundungen. Mede Jahrb 1886; 1: 484-554.

14. Reimann HA. An acute infection of the respiratory tract with atypical pneumonia. JAMA 1933; 111: 2377-2384.

15. Chanock RM, Dienes L, Eaton MD, et al. Mycoplasma pneumoniae: proposed nomenclature for atypical pneumonia organism (Eaton Agent). Science 1963; 140: 662-663.

16. Ritter J. Beitrag zur frage des pneumotyphus (eine hausepidemie in Uster (Schweiz) betreffend). Dtsch Arch Klin Med (Munich) 1880; 25: 53-96.

17. Smith W, Andrewes CH, Laidlaw PP. A virus obtained from influenza patients. Lancet 1933; ii: 66-68.

18. Burnet FM, Freeman M. Experimental studies on virus of "Q" fever. Med J Aust 1937; 2: 299-305.

19. McDade JE, Shepard CC, Fraser DW, Tsai TR, Redus MA, Dowdle WR. Legionnaires' disease: isolation of a bacterium and demonstration of its role in other respiratory disease. N Engl J Med 1977; 297: 1197-1203.

20. Grayston JT, Kuo CC, Wang SP, Altman J. A new Chlamydia psittaci strain, TWAR, isolated in acute respiratory tract infections. $N$ Engl J Med 1986; 315: 161-168.

21. Hamburger M, Schmidt LH, Sesler C, et al. The occurrence of sulfonamide-resistant pneumococci in clinical practice. J Infect Dis 1943; 73: 12-30.

22. Evans W, Hansman D. Tetracycline-resistant pneumococci. Lancet 1962; i: 451.

23. Dixon JMS. Pneumococcus resistant to erythromycin and lincomycin. Lancet 1967; i: 573.

24. Hansman D, Bullen MM. A resistant pneumococcus. Lancet 1967; ii: 264-265.

25. Woodhead M, Macfarlane J, Rodgers FG, Laverick A, Pilkington R, Macrae AD. Aetiology and outcome of severe community-acquired pneumonia. $J$ Infect 1985; 10: 204-210.

26. Alkhayer M, Jenkins PF, Harrison BDW. The outcome of community-acquired pneumonia treated on the intensive care unit. Respir Med 1990; 84: 13-16.

27. Steinhoff D, Lode H, Ruckdeschel G, et al. Chlamydia pneumoniae as a cause of community-acquired pneumonia in hospitalised patients in Berlin. Clin infect Dis 1996; 22: 958-964.

28. BTS Guidelines for the management of community acquired pneumonia in Adults. Thorax 2001; 56: Suppl. 4, 1-64.

29. Pebody RG, Wall PG, Ryan MJ, Fairley C. Epidemiological features of Coxiella burnetii infection in England and Wales: 1984-1994. Communicable Disease Report 1996; 6: R128-R132.

30. el Ebiary M, Sarmiento X, Torres A, et al. Prognostic factors of severe Legionella pneumonia requiring admission to ICU. Am J Respir Crit Care Med 1997; 156: $1467-1472$.

31. British Thoracic Society Research committee. The aetiology, management and outcome of severe communityacquired pneumonia on the intensive care unit. Respir Med 1992; 86: 7-13.

32. Pachon J, Prados MD, Capote F, Cuello JA, Garnacho J, Verano A. Severe community-acquired pneumonia. Etiology, prognosis and treatment. $\mathrm{Am}$ Rev Respir Dis 1990; 142: 369-373.

33. Torres A, Serra-batlles J, Ferrer A, et al. Severe community-acquired pneumonia. Epidemiology and 
prognostic factors. Am Rev Respir Dis 1991; 144: 312318.

34. Rello J, Quintana E, Ausina V, Net A, Prats G. A three year study of severe community-acquired pneumonia with emphasis on outcome. Chest 1993; 103: 232-235.

35. Olaechea PM, Quintana JM, Gallardo MS, Insausti J, Maravi E, Alvarez B. A predictive model for the treatment approach to community-acquired pneumonia in patients needing ICU admission. Intensive Care Med 1996; 22: 1294-1300.

36. Leroy O, Santre C, Beuscart C, et al. A five year study of severe community-acquired pneumonia with emphasis on prognosis in patients admitted to an intensive care unit. Intensive Care Med 1995; $21: 24$ 31.

37. Moine P, Vercken J-P, Chevret S, Chastang C, Gajdos P. Severe community-acquired pneumonia. Etiology, epidemiology and prognosis factors. French Study Group for Community-Acquired Pneumonia in the Intensive Care Unit. Chest 1994; 105: 1487-1495.

38. Sorensen J, Forsberg P, Hakanson E, et al. A new diagnostic approach to the patient with severe pneumonia. Scand J Infect Dis 1989; 21: 33-41.

39. Ortqvist A, Sterner G, Nilsson JA. Severe communityacquired pneumonia: factors influencing need of intensive care treatment and prognosis. Scand J Infect Dis 1985; 17: 377-386.

40. Ortqvist A, Hedlund J, Grillner L, et al. Aetiology, outcome and prognostic factors in communityacquired pneumonia requiring hospitalization. Eur Respir J 1990; 3: 1105-1113.

41. Michetti G, Pugliese C, Bamberga M, et al. Communityacquired pneumonia: is there difference in etiology between hospitalized and outpatients. Minerva Med 1995; 86: 341-351.

42. Berntsson E, Blomberg J, Lagergard T, Trollfors B. Etiology of community-acquired pneumonia in patients requiring hospitalization. Eur J Clin Microbiol 1985; 4: 268-272.

43. Berntsson E, Lagergard T, Strannegard O, Trollfors B. Etiology of community-acquired pneumonia in outpatients. Eur J Clin Microbiol 1986; 5: 446-447.

44. Blanquer J, Blanquer R, Borras R, et al. Aetiology of community-acquired pneumonia in Valencia, Spain: a multicentre prospective study. Thorax 1991; 46: 508 551.

45. Melbye H, Berdal BP, Straume B, Russell H, Vorland L, Thacker WL. Pneumonia - a clinical or radiographic diagnosis? Scand J Infect Dis 1992; 24: 647655.

46. Jokinen $\mathrm{C}$, Heiskanen $\mathrm{L}$, Juvonen $\mathrm{H}$, et al. Microbial etiology of community-acquired pneumonia in the adult population of 4 municipalities in eastern Finland. Clin Infect Dis 2001; 32: 1141-1154.

47. Macfarlane JT, Finch RG, Ward MJ, Macrae AD. Hospital study of adult community-acquired pneumonia. Lancet 1982; ii: 255-258.

48. British Thoracic Society. Community-acquired pneumonia in adults in British hospitals in 1982-1983: a survey of aetiology, mortality, prognostic factors and outcome. Quart J Med 1987; 62: 195-220.

49. White RJ, Blainey AD, Harrison KJ, Clarke SKR. Causes of pneumonia presenting to a district general hospital. Thorax 1981; 36: 566-570.

50. McNabb WR, Shanson DC, Williams TDM, Lant AF.
Adult community-acquired pneumonia in central London. J Roy Soc Med 1984; 77: 550-555.

51. Lim WS, Macfarlane JT, Boswell TC, et al. Study of community acquired pneumonia aetiology (SCAPA) in adults admitted to hospital: implications for management guidelines. Thorax 2001; 56: 296-301.

52. Pareja A, Bernal C, Leyva A, Piedrola G, Maroto MC. Etiologic study of patients with communityacquired pneumonia. Chest 1992; 101: 1207-1210.

53. Falco V, Fernandez de Sevilla T, Alegre J, Ferrer A, Vazquez JMM. Legionella pneumophila. A cause of severe community-acquired pneumonia. Chest 1991; 100: 1007-1011.

54. Gomez J, Banos V, Ruiz Gomez J, et al. Prospective study of epidemiology and prognostic factors in community-acquired pneumonia. Eur J Clin Microbiol Infect Dis 1996; 15: 556-560.

55. Ausina V, Coll P, Sambeat M, et al. Prospective study on the etiology of community-acquired pneumonia in children and adults in Spain. Eur J Clin Microbiol Infect Dis 1988; 7: 343-347.

56. Holmberg H. Aetiology of community-acquired pneumonia in hospital treated patients. Scand J Infect Dis 1987; 19: 491-501.

57. Burman LA, Trollfors B, Andersson B, et al. Diagnosis of pneumonia by cultures, bacterial and viral antigen detection tests, and serology with special reference to antibodies against pneumococcal antigens. J Infect Dis 1991; 163: 1087-1093.

58. Ostergaard L, Andersen PL. Etiology of communityacquired pneumonia. Evaluation by transtracheal aspiration, blood culture or serology. Chest 1993; 104: 1400-1407.

59. Blasi F, Cosentini R, Raccanelli R, et al. Emerging pathogens of community-acquired pneumonia: a twoyear prospective study. J Chemother 1995; 7: Suppl. 4. 115-116.

60. Bohte R, van Furth R, van den Broek PJ. Aetiology of community-acquired pneumonia: a prospective study among adults requiring admission to hospital. Thorax 1995; 50: 543-547.

61. Levy M, Dromer F, Brion N, Leturdu F, Carbon C. Community-acquired pneumonia. Importance of initial non-invasive bacteriologic and radiographic investigations. Chest 1988; 92: 43-48.

62. Aubertin J, Dabis F, Fleurette J, et al. Prevalence of legionellosis among adults: a study of communityacquired pneumonia in France. Infection 1987; 15: 328-331.

63. Hone R, Haugh $\mathrm{C}, \mathrm{O}^{\prime}$ Connor B, Hollingsworth J. Legionella: an infrequent cause of adult communityacquired pneumonia in Dublin. Ir J Med Sci 1989; 158: $230-232$

64. Ruf B, Schurmann D, Horbach I, Fehrenbach FJ, Pohle HD. Incidence and clinical features of community-acquired legionellosis in hospitalized patients. Eur Respir J 1989; 2: 257-262.

65. Farr BM, Kaiser DL, Harrison BDW, Connolly CK. Prediction of microbial aetiology at admission to hospital for pneumonia from the presenting clinical features. Thorax 1989; 44: 1031-1035.

66. Torres A, Dorca J, Zalacain R, et al. Communityacquired pneumonia in chronic obstructive pulmonary disease. A Spanish multicentre study. Am J Respir Crit Care Med 1996; 154: 1456-1461.

67. Woodhead MA, Macfarlane JT. The rise and fall of 
Legionnaires' disease in Nottingham. J Infect 1986; 13: 293-296.

68. Baranda MM, Carranceja JC, Errasti CA. Q fever in the Basque Country: 1981-1984. Rev Infect Dis 1985; 7: 700-701.

69. Kauppinen MT, Saikku P, Kujala P, Herva E, Syrjala H. Clinical picture of community-acquired Chlamydia pneumoniae pneumonia requiring hospital treatment: a comparison between chlamydial and pneumococcal pneumonia. Thorax 1996; 51: 185-189.

70. Wise R, Andrews JM. Local surveillance of antimicrobial resistance. Synercid Resistance Surveillance Group. Lancet 1998; 352: 657-658.

71. Socan M, Marinic-Fiser N, Kraigher A, Kotnik A, Logar M. Microbial aetiology of community-acquired pneumonia in hospitalised patients. Eur J Clin Microbiol Infect Dis 1999; 18: 777-782.

72. Sopena N, Sabria-Leal M, Pedro-Botet ML, et al. Comparative study of the clinical presentation of legionella pneumonia and other community-acquired pneumonias. Chest 1998; 113: 1195-1200.

73. Felmingham D, Gruneberg RN. The Alexander Project 1996-1997: latest susceptibility data from this international study of bacterial pathogens from community-acquired lower respiratory tract infections. J Antimicrob Chemother 2000; 45: 191-203.

74. European Antimicrobial Resistance Surveillance System. Database. www.earss.rivm.n1/PAGINA/interwebsite/home_earss.html. Date last updated: April 2002. Date last accessed: 17 April 2002.

75. Heffelfinger JD, Dowell SF, Jorgensen JH, et al. Management of community-acquired pneumonia in the era of pneumococcal resistance: a report from the DrugResistant Streptococcus pneumoniae Therapeutic Working Group. Arch Intern Med 2000; 160: 1399-1408.

76. Austrian R, Gold J. Pneumococcal bacteraemia with especial reference to bacteraemic pneumococcal pneumonia. Ann Int Med 1964; 60: 759-776.

77. Turett GS, Blum S, Fazal BA, Justman JE, Telzak EE. Penicillin resistance and other predictors of mortality in pneumococcal bacteremia in a population with high human immunodeficiency virus seroprevalence. Clin Infect Dis 1999; 29: 321-327.

78. Metlay JP, Hofmann J, Cetron MS, et al. Impact of penicillin susceptibility on medical outcomes for adult patients with bacteremic pneumococcal pneumonia. Clin Infect Dis 2000; 30: 520-528.

79. Ewig S, Ruiz M, Torres A, et al. Pneumonia acquired in the community through drug-resistant Streptococcus pneumoniae. Am J Respir Crit Care Med 1999; 159: $1835-1842$.

80. Pallares R, Gudiol F, Linares $\mathrm{J}$, et al. Risk factors and response to antibiotic therapy in adults with bacteremic pneumonia caused by penicillin-resistant pneumococci. N Engl J Med 1987; 317: 18-22.

81. Feikin DR, Schuchat A, Kolczak M, et al. Mortality from invasive pneumococcal pneumonia in the era of antibiotic resistance, 1995-1997. Am J Public Health 2000; 90: 223-229.

82. Bartlett JG, Dowell SF, Mandell LA, File-Jr TM, Musher DM, Fine MJ. Practice guidelines for the management of community-acquired pneumonia in adults. Infectious Diseases Society of America. Clin Infect Dis 2000; 31: 347-382.

83. Roson B, Carratala J, Tubau F, et al. Usefulness of betalactam therapy for community-acquired pneumonia in the era of drug-resistant Streptococcus pneumoniae: a randomized study of amoxicillinclavulanate and ceftriaxone. Microb Drug Resist 2001; 7: 85-96.

84. Amsden GW. Pneumococcal macrolide resistancemyth or reality? J Antimicrob Chemother 1999; 44: $1-6$.

85. Waterer GW, Wunderink RG, Jones CB. Fatal pneumococcal pneumonia attributed to macrolide resistance and azithromycin monotherapy. Chest 2000; 118: 1839-1840.

86. Chen DK, McGeer A, de Azavedo JC, Low DE. Decreased susceptibility of Streptococcus pneumoniae to fluoroquinolones in Canada. Canadian Bacterial Surveillance Network. N Engl J Med 1999; 341: 233239. 